\title{
A review of the population dynamics of coregonids in European alpine lakes
}

\author{
Reiner Eckmann*
}

\begin{abstract}
The population dynamics of coregonids in European alpine lakes have been studied intensively during recent decades. Many of these studies have focussed on the impacts of anthropogenic eutrophication and subsequent re-oligotrophication. These changes in productivity represent the single most important perturbation of coregonid habitats since the mid-twentieth century. While the problem of eutrophication has been successfully addressed in many European alpine lakes, new forms of anthropogenic challenge such as climate change and the colonization of lakes by non-native aquatic species continue to impact on coregonid populations and demand research. The picture that emerges from a compilation of primary research papers suggests that abiotic and biotic factors are most influential on year-class strength during the larval phase, exerting more moderate effects during the embryonic and reproductive phases, and only a weak influence during the growth phase. In contrast, individual biomass is mainly determined during the growth phase, but moderate effects on growth may also occur during the larval and reproductive phases. Changes in lake productivity influence the various life-history phases of coregonids in both positive and negative ways, for example by improving feeding conditions and via deterioration of spawning habitat quality. Climate change, on the other hand, seems to influence mainly the embryonic and larval phases, with the available studies suggesting that higher temperatures and earlier onset of stratification in spring tend to boost year-class strength. These effects, however, appear insufficient to balance the marked effects of re-oligotrophication, which has caused and continues to cause a marked depression of growth in many European alpine lakes. The bumper fish harvests obtained during the peak of anthropogenic eutrophication are thus a thing of the past.
\end{abstract}

Keywords: Climate change, competition, eutrophication, predation, year-class strength.

\section{Introduction}

Studies of fish population dynamics are concerned with a range of abiotic (e.g. temperature, oxygen concentration, substrate quality) and biotic factors (e.g. food quantity and quality, competitors, predators, diseases and parasites) that influence the numbers and biomass of fish at all phases within their life cycle. These factors may in turn be influenced by human activities, which might alter a species' habitat or modify the food web to which a particular species belongs. Human impacts on fish stocks are by no means a new phenomenon, but

\author{
Author's address: \\ Limnological Institute, University of Konstanz, 78457 Konstanz, Germany \\ * Corresponding author, e-mail: reiner.eckmann@uni-konstanz.de
}


those associated with today's rapidly changing, globalized world, such as climate change or the accelerating spread of non-native aquatic species, present urgent new challenges. These recently emerging human impacts will also be considered in this review on the population dynamics of coregonids in European alpine lakes.

The lakes lying to the north of the Alps form the southern boundary of coregonid distribution in Central Europe. Many of these lakes are deep, some are even monomictic, thus providing suitable conditions for cold water fish. Coregonids require low temperatures during embryogenesis and therefore most species spawn in late autumn or early winter. Those species that do not spawn in winter, just six from a total of 28 species native to European alpine lakes, are reported to spawn at greater depth (Kottelat \& Freyhof 2007), where temperatures remain low even in summer. Changes in a lake's temperature regime may have a direct impact on the population dynamics of coregonids by altering the rate of embryonic development.

Alpine lakes are oligotrophic in their pristine state, primarily because inputs of the production-limiting element phosphorus from rocky or forested catchments are low, and secondly because phosphorus is effectively immobilized in the oxidized sediments. Any increase in a lake's nutrient content may impact the population dynamics of resident coregonids in at least two ways, i.e. improving the food base for all life stages and deteriorating the quality of spawning grounds through increased consumption of oxygen.

Coregonids dominate the fish communities of pristine European pre-alpine lakes, being replaced only at high altitude by brown trout (Salmo trutta L.) or Arctic charr (Salvelinus alpinus (L.)). Wherever coregonids dominate, they form the basis of important fisheries and commercial interests have driven a long tradition of research into coregonid population dynamics in the region, which includes parts of Austria, France, Germany and Switzerland. By the late nineteenth century, management measures aiming to increase coregonid yields were already being taken, for example the stocking of lakes with artificially hatched larvae, and scientific studies of coregonid population dynamics began in the early century. Pioneers in this emerging field included Kopfmüller \& Scheffelt (1924), Scheffelt \& Schweizer (1926), Lechler (1929), Einsele (1941), Wagler (1941) and Elster (1944). The research continued into the latter half of the $20^{\text {th }}$ century, when it was taken up at many research institutes, universities and by management agencies: in Austria, the Austrian Academy of Sciences at Mondsee (the Lakes Attersee, Hallstatt, Mondsee, Wallersee) and the Federal Agency for Water Management at Scharfling (the Lakes Irrsee, Mondsee, Zellersee); in France, INRA at Thonon (Lakes Annecy, Bourget, Geneva); in Germany, the Bavarian State Institute for Fisheries at Starnberg (Lakes Wörth, Starnberg), the Fisheries Research Station at Langenargen (Lake Constance), the Institute for Lake Research at Langenargen (Lake Constance), the State Office for Water Management at Wielenbach (the Lakes Ammersee, Chiemsee, Kochelsee, Walchensee), and the University of Konstanz (Lake Constance); and in Switzerland, the Conservation de la faune, St-Sulpice (Lakes Joux, Neuchâtel), EAWAG at Kastanienbaum (Lakes Hallwil, Lucerne, Sarnen, Sempach), the Fisheries Administration of St.Gall (Lakes Constance, Walenstadt), and University of Bern (Lakes Biel, Brienz, Thun).

Despite the large number of publications appearing over recent decades, the population dynamics of coregonids in European alpine lakes remains far from fully understood, and anthropogenic impacts on these lakes mean that continued research is required to track the responses of coregonid stocks to changing environmental conditions. Many studies have 
been published in primary peer-reviewed journals, but more are widely distributed in non peer-reviewed national journals, in project reports and other grey literature outlets. This review focuses on our current understanding of the population dynamics of coregonids in alpine lakes, drawing mainly from the peer-reviewed literature of recent decades. Whenever peer-reviewed publications from the alpine region are lacking, data from grey literature sources, data obtained in other parts of the coregonid distribution range and data from earlier classical studies is included where it helps to make a certain point. To avoid confusion for those who wish to consult the original publications cited herein, the species names used in the original articles are left unchanged, even though they may not conform to the actual (Kottelat \& Freyhof 2007) species denomination.

\section{The embryonic phase}

Coregonids are open substrate spawners that do not guard their eggs or young. Hence, the eggs are exposed directly and irrevocably to prevailing environmental conditions at the site where they come to rest. The success of embryonic development, i.e. the proportion of viable larvae hatching from deposited eggs, will then depend on the oxygen concentration of the water, substratum quality, and the rates of infection of the eggs by fungi and consumption by egg predators. The minimum oxygen concentration for successful natural reproduction in whitefish (Coregonus lavaretus (L.)) is generally regarded as $4 \mathrm{mg} \mathrm{L}^{-1}$ (Müller \& Stadelmann 2004), below which the percentage of normal fry decreases notably, e.g. lake herring (Coregonus artedi Leseur) (Brooke \& Colby 1980). Lower concentrations may induce precocious hatching in $C$. lavaretus, in which sensitivity to hypoxic stress increases with progressing development, and the response to hypoxia is stronger at higher temperature (Czerkies et al. 2001). The increase in sensitivity to hypoxia as embryogenesis progresses is clearly related to the higher oxygen demand of advanced embryos: at $4^{\circ} \mathrm{C}$ the oxygen consumption of 100 eggs of Coregonus lavaretus wartmanni Bloch increased from $16 \mu \mathrm{L} \mathrm{h}^{-1}$ at day 15 to $34 \mu \mathrm{L}$ $\mathrm{h}^{-1}$ at day 45 (Braum \& Quos 1981).

Even under favourable oxygen concentrations in the water column, embryos may suffocate when the oxygen gradient at the sediment-water interface is too steep. Whitefish eggs, which are negatively buoyant, rest directly on the substratum and may be deprived of oxygen in the diffusive boundary layer (Müller 1992, Müller \& Stadelmann 2004). The greater the rate of oxygen consumption due to mineralization of organic matter in the sediment, the steeper is the oxygen gradient in the diffusive boundary layer. Even at oxygen concentrations as high as $10 \mathrm{mg} \mathrm{L}^{-1}$ in the water above the sediment, egg mortality has been reported (Müller 1992).

When eggs are spawned over suitable substrata with sufficient oxygen in the sedimentwater interface, they may still be relocated to zones of steep oxygen gradients and/or lower mean oxygen concentrations (Ventling-Schwank \& Livingstone 1994). Current speeds of 10 to $15 \mathrm{~cm} \mathrm{~s}^{-1}$ at $0.5 \mathrm{~m}$ above the sediment surface were sufficient to transport coregonid eggs, together with fine silt and clay, into deeper regions of Lake Sempach, Switzerland. In addition to the risk of relocation to less suitable sites, egg burial also seems likely. In Lake Joux, Switzerland, Coregonus fera Jurine spawn over substrata without soft mud, where egg development is generally successful. But the eggs may be carried away by currents and come to rest at greater depth on soft muddy parts of the lake bed, where most eggs were found to 
be dead and infected by Saprolegnia (Büttiker 1986). Lake impoundment may lead to eggs being buried in silty clay with a low organic content. The siltation of Coregonus clupeaformis (Mitchill) eggs after the impoundment of Southern Indian Lake, Canada, increased egg mortality, not through the oxygen demand of the sediment itself but rather because the sediment acted as a physical barrier to oxygen and metabolic wastes being transported towards and away from the eggs, respectively (Fudge \& Bodaly 1984).

As coregonid eggs are so susceptible to low oxygen concentrations, the natural reproduction of coregonids in many European alpine lakes was compromised by anthropogenic eutrophication during the second half of the twentieth century. In the case of Lake Constance whitefish, between 1967 and 2006 the proportion of viable eggs at 170 to $250 \mathrm{~m}$ depth correlated with the concentration of oxygen measured at about $1 \mathrm{~m}$ above the bottom (Wahl \& Löffler 2009). The worst oxygen conditions were registered during the 1970s and $1980 \mathrm{~s}$ when the lake was most affected by anthropogenic eutrophication (total phosphorus $>30 \mu \mathrm{g}$ $\mathrm{L}^{-1}$ ). In some of these years, conditions for whitefish egg development were further degraded through reduced renewal of deepwater oxygen by vertical mixing. The data suggest that oxygen concentrations below $6 \mathrm{mg} \mathrm{L}^{-1}$ at about $1 \mathrm{~m}$ above the bottom will result in an almost complete loss of the eggs (Wahl \& Löffler 2009). Swiss examples from lakes Sempach, Hallwil and Baldegg have clearly demonstrated that even if intra-lake measures such as hypolimnetic oxygenation and artificial mixing are favourable for juvenile and adult fish and their food base, normal development of coregonid eggs can only be achieved through a reduction in lake nutrient content and a concomitant decrease in oxygen consumption by the sediment (Müller \& Stadelmann 2004).

Coregonid eggs are generally unprotected from consumption by both invertebrate and vertebrate predators, because as open substrate spawners sensu Wootton (1998) they do not guard their eggs and young. Predation pressure is probably mitigated to some extent by the low temperatures at which egg development takes place, but there are fish species that tolerate low temperatures and do not stop feeding in cold water, and these are potential predators of coregonid eggs. Burbot (Lota lota (L.)), the only freshwater gadiform species, usually cooccurs with coregonids in European alpine lakes. Elster (1944) repeatedly observed several hundred whitefish eggs per burbot stomach in Lake Constance, with a peak value of 1,800 eggs in a 'medium-sized' individual. Occasional stomach content analyses of the deepwater ecotype of Arctic charr revealed that these fish must also be considered as predators of whitefish eggs (Elster 1944).

Egg cannibalism has been thoroughly studied in C. lavaretus in a Norwegian river. Females were more cannibalistic than males, and eggs were taken from the open water as well as from the substratum. Roe consumption contributed to an egg mortality of a least $8.8 \%$. These data are consistent with an evolutionary model predicting that cannibalism represents an evolutionarily stable strategy if cannibals gain more by this behaviour in terms of fitness than they lose in terms of survival rate. The fitness gain may be due to increased fertility or increased survival (Skurdal et al. 1985). Egg cannibalism has also been reported for C. clupeaformis in Lake Ontario, C. lavaretus in a Norwegian lake, and for Coregonus autumnalis migratorius Georgi in Lake Baikal (see references in Skurdal et al. 1985), but it has apparently not been investigated in detail in alpine lakes.

Researchers and managers regained an interest in predation on whitefish eggs when the ruffe (Gymnocephalus cernuus (L.)) expanded its distribution range throughout Central 
Europe in the 1980s. It was feared that this versatile species may have negative effects on the recruitment of nearshore spawning whitefish (Winfield et al. 1998a, b). Ruffe were indeed found to consume whitefish eggs during spawning time in early December and up to midJanuary in Lake Constance (Schmid 1998). A maximum of $322 \mathrm{eggs}$ was found in the stomach of a ruffe $16 \mathrm{~cm}$ long and weighing $60 \mathrm{~g}$, but no more than $60 \%$ of ruffe were found to have consumed whitefish eggs (Rösch \& Schmid 1996). There is no evidence so far that egg predation by ruffe influences whitefish recruitment in alpine lakes.

Egg predation by invertebrates seems to be uncommon or is rarely documented, except for one experiment conducted in Lake Constance in 1972. Whitefish eggs were exposed in mesh cages for four to seven weeks at $160 \mathrm{~m}$ depth. When the cages were retrieved, many empty egg shells were found, particularly in those cages that had been in direct contact with the sediment, and many turbellarian flatworms were present, some of them firmly attached to whitefish eggs (Nümann \& Quoß 1972). These turbellarians perforate the chorion and suck out the content of the egg. Dendrocoelum lacteum (Müller) was the most abundant flatworm species and because it is characteristic of polluted waters, the authors speculated that the density of turbellarians, and hence the predation on whitefish eggs, might have increased in parallel with lake eutrophication. After lake re-oligotrophication, turbellarians continue to prey on whitefish eggs (Author, pers. obs.), but no quantitative data on their possible impact on recruitment are available.

In addition to the human impacts outlined above, climate change may affect the development of whitefish eggs in alpine lakes. These influences may act directly via increased temperature or indirectly via changes to the mixing regime of deep monomictic lakes. Higher water temperature during winter will accelerate embryogenesis and so reduce the length of time the eggs are potentially exposed to predators, insufficient oxygen supply and the risk of infection with fungi. All other environmental factors being equal, mortality during the embryonic stage might therefore decrease. The statistical analysis of a long-term data set from Lake Constance has indeed found evidence that higher hypolimnetic temperature, ranging between 3.8 and $5.1{ }^{\circ} \mathrm{C}$, is coupled with stronger year-classes of pelagic spawning whitefish (Straile et al. 2007). As climate change tends to increase the temperature in the hypolimnion of deep alpine lakes, we may expect stronger whitefish year-classes in the future. But earlier hatching of larvae is not necessarily advantageous in promoting stronger year-classes. When earlier hatching leads to a mismatch between whitefish larvae and their prey, better survival during the embryonic stage might be more than compensated by losses due to starvation during the eleutheroembryonic stage (see below, the larval phase).

A further influence of climate change on whitefish population dynamics may arise via modification of lake mixing regimes. The steepness of the oxygen gradient in the diffusive boundary layer depends on both the rate of oxygen consumption by the uppermost sediment layer and on the oxygen concentration in the water column above. In stratified lakes, the oxygen content of the near-bottom water body is replenished during vertical mixing. Any changes in the mixing pattern of lakes may therefore modify the oxygen gradient in the diffusive boundary layer and ultimately impair embryogenesis. A warm winter can inhibit mixing of the water column in deep alpine lakes, particularly when the previous winter was a cold one. This happened in the winter of 2006/2007 at Lake Constance when the lake $\left(\mathrm{z}_{\max }=\right.$ $254 \mathrm{~m}$ ) did not mix below $60 \mathrm{~m}$ depth (Straile et al. 2010). As winters become warmer, conditions for the embryonic development of whitefish eggs incubated in deep lake regions will 
probably deteriorate. This effect will be most pronounced in lakes that have not yet recovered completely from eutrophication, i.e. where sediment oxygen consumption remains elevated.

In summary, it can be said that the conditions for proper embryonic development have improved considerably in most European alpine lakes during the last decades due to lake restoration measures, and that the consumption of eggs by vertebrate and invertebrate predators seems to be inconsequential for coregonid population dynamics. Overall, the effects of abiotic and biotic factors on the coregonids embryogenesis have only a moderate effect on year-class strength.

\section{The larval phase}

Since the early days of fish population dynamics research, the larval phase has always been considered to be of paramount importance in the control of cohort size (Cushing 1990). Losses during this phase can occur due to insufficient or inappropriate food supply or as a result of predation, and larvae in a poor nutritional state face an increased predation risk. The 'bigger-is-better' paradigm (Miller et al. 1988, Bailey \& Houde 1989) provides an integrated framework for understanding why high growth rates during the larval phase are generally associated with large cohort sizes: (i) the bigger a larva grows, the sooner it gets access to a broader prey spectrum and can profit from the consumption of bigger, energy-rich prey items, (ii) larger larvae have better visual acuity and higher cruising speed, allowing them to search a larger water volume for food, (iii) large larvae may tolerate periods of food shortage better than smaller conspecifics, and (iv) bigger larvae face a lower predation risk due to their higher burst speed, which reduces the capture success of predators and also due to their larger size per se which sets a lower limit to the size of gape-limited predators. Hence, any factor that enhances the growth of larval fish might increase cohort size.

The most prominent growth regulating factor in ectothermic organisms is temperature, which can operate directly via its influence on metabolic rates as well as indirectly by modifying various behavioural performances. For example, during the first days after hatching, coregonid eleutheroembryos improve prey capture success by practice, whereby the rate of improvement increases with temperature. Braum (1964) observed a prey capture success of only $3 \%$ in $0-8$ day old whitefish larvae. This value increased by practice to around $20 \%$ in 9-16 days old larvae, whereas naïve larvae of the same age fared no better than recently hatched larvae. Higher temperatures led to improved capture success: at $5.3^{\circ} \mathrm{C}$ larvae were successful in only $4.1 \%$ of capture attempts after 11 days, while at $12^{\circ} \mathrm{C}$ capture success was $31.2 \%$. Higher temperature not only enhanced the fine-tuning of the snapping behaviour, it also improved the capture success in older, experienced larvae through the direct effect of temperature on activity (Braum 1967).

The combined influence of various direct and indirect temperature effects on growth may be revealed by an analysis of the temperature dependence of coregonid larvae growth in situ. This approach was followed by Eckmann \& Pusch (1989) using length-frequency and daily otolith increment analyses of larval and juvenile whitefish, respectively. When comparing length-frequencies of larvae sampled in two consecutive years it became obvious that the growth of larvae was advanced by about 10 days in the year when the spring warming of the lake's surface waters started around 10 days earlier. A more detailed analysis of larval 
growth in early spring was based on otolith increment analysis. This clearly showed that growth during April and May tracked surface water temperature very closely, irrespective of zooplankton concentration. Based on this close correspondence between temperature and daily growth rate, the growth of whitefish larvae was modelled by advancing the observed temperature time series by five days. Under this scenario, larvae would have been $6 \%$ larger and $23 \%$ heavier than actually observed after 70 days, suggesting that even subtle differences in meteorological conditions may exert marked effects on larval and juvenile growth. Survival of the larvae would also increase notably under this scenario: based on a generalized relationship between capture success and predator-prey size ratio (Miller et al. 1988), capture success of a $20 \mathrm{~cm}$ predator for example would decrease from $42 \%$ for larvae grown under the observed temperature pattern to $38 \%$ for larvae grown under the advanced scenario. However, in order to benefit from an earlier onset of lake warming the larvae would need to live in the uppermost layer of water. This is particularly important in large and deep alpine lakes where an evolving temperature gradient in early spring may easily be eroded by strong winds. Whitefish larvae were indeed found to be concentrated in the uppermost $3 \mathrm{~m}$ of water from March to May, and in an experimental vertical temperature gradient they showed a significant preference for the warmest layer in a range from 1 to $16^{\circ} \mathrm{C}$ (Eckmann 1989).

A growth advantage of larvae and juveniles at higher temperature, however, is only indicative of a temperature effect on cohort size. A statistically significant correlation between longterm records of temperature and cohort size has generally been considered as convincing evidence for a causal relationship. This approach was pioneered at Lake Constance by Hartmann (1983a,b) and taken further by Wetzlar (1983), Eckmann et al. (1988) and Hartmann (1988), and at Lake Geneva by Gerdeaux \& Dewaele (1986). Even though these authors used different sets of predictor variables in their analyses, they agreed that meteorological factors during the early life stages exert a strong influence on the size of the adult cohort subsequently harvested by the commercial fishery, i.e. virtual year-class strength (YCS). Other factors, such as oxygen concentration close to the lake bottom during embryonic development, zooplankton abundance in early spring, or stocking with hatchery-bred larvae were either not significantly related to cohort size, or their effects ranked second to meteorological factors. A similar analysis for Lake Geneva whitefish, even though it was not based on cohort size data but on fishery yield, showed a significant correlation between catch volume and temperature two years earlier (Gerdeaux \& Dewaele 1986).

The influence of meteorological factors on year-class strength of whitefish was re-evaluated by Straile et al. (2007) for a 52-year period from 1947 to 1998. Climate variability associated with the North Atlantic Oscillation (NAO) was significantly related to YCS in two ways, i.e. through the temperature effect on larval growth during early spring, and through the temperature effect on egg development time. The latter effect is related to the NAO with a time lag of one year, because the temperature during holomixis in spring determines the temperature at which the eggs laid at the start of the following winter will develop. A warm winter in the year before spawning will lead to an earlier hatching of larvae and hence to reduced losses during the embryonic phase.

Another line of evidence comes from the analysis of long-term temperature changes in alpine lakes and their relation to cohort size and fishery yield. For example, an increase of the mean annual temperature at $5 \mathrm{~m}$ depth in Lake Geneva by around $1^{\circ} \mathrm{C}$ from 1970 to 2000 was said to have contributed to improved recruitment of whitefish (Gerdeaux 2004). In this 
case the positive influence of increased temperature was attributed to an earlier onset of the production cycle in spring, allowing whitefish larvae to benefit from better food conditions earlier in the year. A further analysis of the whitefish stock in Lake Geneva demonstrated a rather abrupt shift in the stock-recruitment relationship in the late 1980s, which was related mainly to large-scale meteorological factors (Anneville et al. 2009). Higher spring water temperature in the later years may have improved larval survival and subsequent recruitment into the commercial fishery by creating a better temporal match between the hatching of larvae and their zooplankton prey and by the direct influence of temperature on larval growth.

Even when the temperature is favourable for the growth of whitefish larvae, high growth rates can only be achieved with a supply of suitable sized prey present in sufficient concentration at the right time. While there are many studies on the diet of larval whitefish in European alpine lakes (Hartmann 1983b, 1986, Niesslbeck \& Klein 1988, Ponton \& Müller 1988, Ruhle 1988, Morscheid \& Mayr 2002), few have attempted to quantify the relationship between food supply and cohort size, mediated by larval survival and growth. Rellstab et al. (2004) fed newly hatched whitefish larvae from Lake Lucerne with Artemia nauplii and zooplankton and found a clear relationship between food concentration and larval mortality during the first 34 days. With 20 zooplankton organisms per litre or fewer, moitality reached up to $40 \%$ and more. A decrease had been observed in the late winter/early spring concentration of zooplankton organisms usable by whitefish larvae in Lake Lucerne during the 1980s and 1990s, and this effect of re-oligotrophication was considered to be one factor contributing to the reduction in year-class strength of the slow-growing form of whitefish in the lake.

A starvation mortality of whitefish in Lake Constance was analyzed by Braum (1964) during the early phase of anthropogenic eutrophication. He combined data on the larval visual field, prey capture success and daily food requirement with in situ zooplankton concentration data and concluded that larvae had fair survival prospects considering the actual zooplankton supply and the larvae's ability to exploit this resource. Several decades later, during the early phase of re-oligotrophication, the dependency of Lake Constance whitefish larvae growth on zooplankton concentration during spring was analyzed repeatedly (Eckmann \& Pusch 1989, Eckmann \& Pusch 1991, Rey \& Eckmann 1989). Temperature was the single most important influencing factor, and while an effect of food concentration on growth rate could not be detected, starvation induced mortality could not be ruled out. Again, as in the case of the temperature influence on cohort size, multivariate regression analysis was used to evaluate the relationship between zooplankton concentration during the early feeding phases of whitefish larvae and the resulting year-class size. The results are controversial, as two studies found a significant correlation between the concentration of small-sized zooplankton in April or April/May and cohort size (Wetzlar 1983, Hartmann 1988), while no such correlation was found in a third study (Eckmann et al. 1988). These three studies were based on a maximum of 23 years of data, encompassing the phase of rapid eutrophication in the early 1960s and the beginning of lake re-oligotrophication in the early 1980s. High phosphorus concentrations and consequently enhanced primary and secondary production during these years might have obscured a correlation between food concentration and cohort size. However, in the study by Straile et al. (2007), incorporating 37 years of data from 1962 to 1998 , total phosphorus concentration during winter mixing, taken as a proxy for lake productivity, was not related to whitefish cohort size either. All these results combined suggest that food supply during the early life stages is probably not a prominent driver of whitefish cohort size under a wide 
range of trophic conditions, but that in extremely oligotrophic lakes food restrictions for first feeding larvae may prevent the formation of strong cohorts.

The match and mismatch between fish larvae and their zooplankton prey has long been considered as an important driver of cohort size in the marine domain (Cushing 1990). This concept began to receive increased attention among freshwater fisheries biologists when the consequences of climate change on fish population dynamics became a subject of key concern. Winter-spawning coregonids are particularly vulnerable to a mismatch with their prey, as coregonid larvae hatch during a time when zooplankton production is only about to start. An earlier onset of the productivity cycle might therefore improve food conditions for first feeding larvae, and all other things being equal, result in stronger year-classes. Empirical data on this topic, however, are inconclusive.

In Lake Geneva the emergence of early developmental stages of cyclopoid copepods has been occurring earlier in the year since the mid-1980s (Anneville et al. 2009). The hatching date of coregonid larvae was slightly advanced as well, but the interval between the emergence of cyclopoid copepods and the hatching of whitefish larvae decreased significantly. The interval was shorter during high NAO years (1988-2003) than in low NAO years (19741987). This measure of match/mismatch between predator and prey contributed around $15 \%$ to the first axis of a Principal Components Analysis on whitefish catches from Lake Geneva for the years 1974-2003.

By contrast, in Lake Constance, analysis of a 52-year time series of whitefish YCS did not provide any evidence for a mismatch between whitefish larvae and their prey (Straile et al. 2007). This is noteworthy, since the hatching of whitefish larvae and the onset of the spring plankton bloom are triggered by two independent factors. The duration of embryogenesis and hence the hatching date of whitefish is linked to the NAO index of the previous winter, whereas the phenology of larval prey is determined by the current NAO index. This is due to the lake being monomictic with holomixis occurring in late February/early March. Hence the eggs are incubated in the hypolimnion at the temperature that was established during the previous holomixis while the larvae experience the actual winter conditions. The apparent absence of a mismatch in this population was attributed to starvation resistance of whitefish larvae and to the presence of suitable food items for first feeding larvae, for example Eudiaptomus gracilis (Sars) which reproduces as early as February in this lake (Seebens et al. 2007).

Parasites and diseases of whitefish larvae in European alpine lakes have been studied only rarely. Nümann (1973) argued that many whitefish, particularly young individuals, will probably die from cestode infections, but did not consider these losses important in the control of cohort size. A severe intestinal disorder of unknown aetiology affected the whitefish larvae in Upper Lake Constance in several years in the 1980s and 1990s (Eckmann 1985, Eckmann et al. 1986, Eckmann \& Rösch 1998). The symptoms were first detected in hatcheries when the larvae were fed with copepod zooplankton from the lake, but they were also documented in wild larvae (Steinhart \& Eckmann 1992). A multivariate statistical analysis demonstrated that this disorder at the larval stage had a strong impact on the size of the growing-up cohort, because whitefish YCS was significantly lower in all those years in which the symptoms were detected in hatcheries and laboratories (Straile et al. 2007).

UV-B radiation may have negative effects on fish, but there are no data suggesting that ambient levels of UV radiation, even under the conditions of ozone depletion, would affect whitefish population dynamics. Whitefish and vendace (Coregonus albula (L.)) larvae 
produced more melanin after exposure to sub-ambient and above-ambient doses of UV-B, but no effect on mortality, growth or metabolic rate was observed (Häkkinen et al. 2002). The effects of high levels of UV radiation may even be less pronounced under field conditions, because whitefish and vendace larvae avoid UV radiation both in the laboratory and in the field, and the avoidance behaviour was more pronounced in lakes with low concentrations of organic carbon (Ylönen \& Karjalainen 2004)

Predation on larval fish is notoriously difficult to evaluate in the field, given the speed with which the larvae can be digested, often leaving no identifiable remains after an hour or two (Folkvord 1993, Schooley et al. 2008). Accordingly, there are few studies documenting the consumption of coregonid larvae by fish predators (Loftus \& Hulsman 1986, Haakana \& Huuskonen 2009), and these do not relate to European alpine lakes. In Lake Hallwil, Switzerland, cannibalism was suspected to influence the population dynamics of whitefish, but despite their efforts to document cannibalism, Enz et al. (2001) did not find any identifiable larvae in the stomachs studied. However, mortality of fish is generally high during the larval stage and several studies of whitefish population dynamics in European alpine lakes provided strong evidence that cohort size is indeed determined mainly during the larval and early juvenile phases. Losses during these stages have mainly been attributed to predation, and both multivariate regression analyses (Eckmann et al. 1988, Straile et al. 2007) and stock-recruitment modelling (Caranhac \& Gerdeaux 1998) suggest that predation losses are mainly due to cannibalism. The lack of direct proof for cannibalism in European alpine whitefish populations is most probably due to insufficient effort and/or inappropriate sampling strategies.

The general picture that emerges from the above studies is that lake productivity affects the relative importance of two important causes of whitefish mortality during the larval stage. As long as a lake is oligo- to mesotrophic, starvation is probably not an important cause of mortality, but (intraspecific) predation appears to be the dominant cause. Under ultraoligotrophic conditions, however, insufficient food for whitefish larvae may indeed constrain cohort size. This is not to say that predation is less important under these conditions. On the contrary, reduced food supply leads to slower growth so that the larvae remain vulnerable to gape-limited predators for a longer time. Hence, starvation may occur in mesotrophic lakes, but its impact on cohort size becomes apparent only in ultra-oligotrophic lakes. Predation, on the other hand, is always an important cause of losses, but the magnitude may be enhanced in the least productive lakes. Overall, the effects of abiotic and biotic factors on coregonid larval development have a strong effect on year-class strength but only a moderate effect on individual biomass.

\section{The growth phase}

The growth rate of fish is generally highest during the larval and early juvenile phase, even though the absolute gain in body weight at this stage is small. Minor changes in growth rate during early ontogeny may have a huge impact on a species' population dynamics by controlling the number of individuals that will later recruit into the reproductive stock (cf. above). However a second component of fish population dynamics, the biomass of individual fish, is determined mainly during the subsequent growth phase. Even though growth rates during this stage are lower than in the earliest phase of ontogeny, the absolute gain in weight is large. 
How much weight an individual fish gains depends on the amount of food available, which in turn is influenced by factors such as predation risk or adverse abiotic factors, and through intra- and interspecific competition.

When coregonids colonized European alpine lakes after the last glaciation, they coped well with the limited food supply during a long period (thousands of years) of oligotrophic conditions. Subsequently, during the anthropogenic eutrophication period of the twentieth century, fish exhibited greatly enhanced growth. Yields of whitefish increased between twoand five-fold, and higher yields have generally been attributed to greater individual weight rather than to larger cohort size (Nümann 1973, Kirchhofer \& Tschumi 1986, Müller 1993, Ruhle \& Gammeter 1998). The implementation of more efficient monofilament nylon gill nets, however, also played a significant role in the yield increases. As a result of faster growth, fish were harvested at a younger age, so fewer cohorts were harvested simultaneously. Differences in cohort size between successive years therefore became much more apparent than in the decades prior to eutrophication. For example, the highest-to-lowest yield ratio in the Lake Constance whitefish fishery during the first half of the twentieth century was $3: 1$, but it increased to $9: 1$ thereafter. By the beginning of the twenty-first century, most European alpine lakes had returned or were returning to oligotrophic conditions, and the growth of whitefish reverted to levels characteristic of nutrient-poor alpine lakes.

When fish are confronted with a predation risk, their access to food resources may be constrained by a behaviourally mediated trade-off between growth and survival. In the case of pelagic zooplanktivorous fish, predator avoidance would generally be accomplished by diel vertical migration (DVM). DVM may lead to a mismatch in the distribution of fish and their zooplankton prey, leading to slower growth. In Muddusjärvi, for example, piscivorous brown trout patrolled the pelagic habitat continuously, inducing DVM in pelagic whitefish (Kahilainen et al. 2009). Vendace in Lake Stechlin performed DVM in all months (Mehner et al. 2007). As their vertical distribution was not related to the distribution of their potential predators or that of their prey, DVM was interpreted as a genetically fixed behaviour to minimize the anticipated potential predation risk. In a follow-up study, the metabolic costs and benefits of DVM were analysed using a bioenergetics-based foraging model, showing that DVM was not the most efficient strategy performed by coregonids in Lake Stechlin (Busch et al. 2011). In European alpine lakes no dedicated studies have been conducted so far on the impacts of actual or anticipated predation risks on the distribution of zooplanktivorous whitefish, or on the potential energetic benefits of DVM.

Access to zooplankton prey in the pelagic zone may also be constrained by barriers that impede the free vertical and horizontal movement of fish. In Ammersee, Germany, whitefish avoided areas with high turbidity in both horizontal and vertical planes (Mayr 2002). During periods of elevated turbidity caused by high inflows from the main tributary, whitefish moved into deeper water where feeding conditions were poor and consequently stomachs were largely empty. Such conditions may last for several weeks, and they are considered a factor in the poor growth of Ammersee whitefish (Morscheid \& Mayr 2002). Values of turbidity lower than those observed in Ammersee, however, may be correlated positively with whitefish density. Satellite data on turbidity and hydroacoustic fish density estimates in Upper Lake Constance showed significant correlation in each of five surveys (Heege \& Appenzeller 1998). The turbid north-eastern region may have been preferred by the fish because conditions disadvantaged visual fish predators or because the nutrient-rich river inflows increased 
primary and secondary production, providing more food for the fish. Precise quantitative estimates of the relative benefits of high or low water turbidity are not available.

Another factor that may constrain whitefish access to pelagic zooplankton, or which may reduce their growth rate by toxic effects, is the occurrence of cyanobacterial blooms. As lake restoration measures take effect, the conditions for metalimnetic cyanobacterial blooms improve (Ernst et al. 2001). These blooms result in metalimnetic oxygen minima that may restrain fish from moving to shallower, plankton-rich waters. Additionally, cyanobacteria have been found in the gut contents of Ammersee whitefish, and average body weight of these fish has decreased markedly since the early 1990s. Oral application of mycrocystin-LR provoked behavioural and physiological changes as well as histopathological changes in the liver and gastrointestinal tract (Ernst et al. 2006). Furthermore, eggs and larvae sampled during cyanobacterial blooms showed malformations typical for cyanobacterial toxin exposure (Ernst et al. 2001). As conditions suitable for cyanobacterial blooms are likely to arise in other lakes, these influences on whitefish early development and growth deserve further study.

Even when a fish has free access to an appropriate food supply, its share of this resource will depend on the strength of intra- and interspecific competition. Whitefish are known to feed very selectively, yet are able to adapt very flexibly to changes in their prey spectrum (Becker \& Eckmann 1992, Mookerji et al. 1998, Enz et al. 2001). With decreasing food abundance, however, competition will increasingly restrict whitefish growth. In Lake Annecy for example, there was some dietary overlap between whitefish and Arctic charr. This was not considered as a severe feeding competition (Gerdeaux et al. 2002), but should the whitefish shift their diet under more severe competition to include more cyclopoid copepods, the prevalence of the tapeworm Proteocephalus longicollis Zeder, which is transmitted by cyclopoids (Hanzelova et al. 1999), might increase with so far unknown consequences for whitefish growth.

Individuals within a population are most similar in their resource requirements and therefore are likely to compete most severely for food between themselves rather than with heterospecifics (Wootton 1998). When a food resource is limited, the share an individual obtains will be directly related to the population density. All other things being equal, in particular food resource level, evidence for competition for food can be obtained by comparing growth and population density. But the food base for whitefish in European alpine lakes changed almost continuously during the second half of the twentieth century, so simple comparison of whitefish growth and population density will not provide an unequivocal picture.

Nevertheless, one very general conclusion can be drawn from the observed changes in the growth of whitefish in European alpine lakes during recent decades. In practically all lakes that were affected by eutrophication, growth of whitefish increased, in many cases dramatically so. This implies that fish growth potential was only partly realized under oligotrophic conditions; hence competition for food must have been severe. Under eutrophic conditions, intraspecific competition for food was obviously relaxed, but whether it continued to influence whitefish growth, and to what degree, is not so easy to evaluate. Density-dependent growth of coregonids has been demonstrated repeatedly (Hamrin \& Persson 1986, Marjomäki \& Kirjasniemi 1995, Mills et al. 1995, Todd \& Davis 1995), but only few quantitative studies have been done in European alpine lakes. This may be attributed to the widely accepted notion that whitefish in European alpine lakes can be considered as classic examples of trophy-mediated growth acceleration and earlier maturation (Eckmann et al. 2007). With 
hindsight, however, it seems that the apparently powerful impact of anthropogenic eutrophication on fish growth tended to mask the role of population density on individual growth (Nümann 1972, Rufli 1979, Müller 1993, Pedroli 1983, Kirchhofer 1995, Eckmann \& Rösch 1998). The prominent role of eutrophication in the changing whitefish population dynamics was questioned explicitly by Hartmann (1987), who considered whitefish to be poor indicators of changes in lake productivity. Kirchhofer \& Tschumi (1986) reported that growth of the fast-growing whitefish form in Lake Thun accelerated during the 1970s/1980s, a phenomenon they attributed to the small population size. The authors also mentioned longer growing seasons in two years and ongoing eutrophication as additional factors, though they could not weight the relative importance of these factors in the observed growth acceleration. A comparison between growth and hydroacoustic density estimates of Ammersee whitefish over six years revealed a rather tight relationship, in which the weight of 4 year old fish decreased by around $40 \%$ with a five-fold increase in fish density (Mayr 2001). Whitefish growth and abundance were compared in Traunsee and Hallstättersee, Austria, by Wanzenböck et al. (2002). Their data suggested that intraspecific competition for food was the main reason for slower growth of whitefish in Hallstättersee. In Traunsee on the other hand, overfishing ameliorated intraspecific competition leading to faster growth, irrespective of the lower productivity of this lake. A higher biomass and higher average size of crustaceans in Traunsee confirmed the conclusion that fish abundance influences whitefish growth much more than phosphorus concentration.

Recently Thomas \& Eckmann (2007) quantified the importance of lake productivity and population density for the growth of 43 consecutive whitefish cohorts by multivariate regression analyses. They found that growth was most strongly related to standing stock biomass, followed in second place by phosphorus content during holomixis, which was taken as a proxy for food abundance. In addition to the most evident direct impact of population density on individual growth, there is a more subtle, indirect influence on growth. The higher the population density, the longer it takes for a fish to reach a certain size, and the more energy is allocated to metabolism. It would thus be most economical to adjust whitefish population sizes to levels that permit highest yield for a given level of productivity. This demanding approach, however, has not been attempted by fishery managers in European alpine lakes so far.

The reason population size is not a central target for fishery management lies in the way coregonid fisheries in European alpine lakes are managed. To the author's best knowledge, no quotas are set in any of the lakes. Instead, the fisheries are managed by restrictions on fishing effort, such as mesh size, number of licenses, fishing days per week etc. In this way fish are harvested more or less as soon as they are recruited into the fishery. This type of management has the advantage that immature fish can be spared by selecting an appropriate mesh size/ legal size limit. In a properly managed fishery, recruitment overfishing will not be a problem (Nümann 1972, Müller \& Bia 1998). The drawback is that the size of the non-recruited population is not controlled. The larger this population, the longer the time span until the fish will be recruited into the fishery. In this situation, more energy is allocated to metabolism, and the harvest potential at a given level of lake productivity will not be fully realized.

A second and probably more severe problem with using mesh size regulation to control fishing effort is the potential for a fishery-induced trend towards slower growth. While fishery-induced evolution has already become a topic of prime importance in marine fisheries 
(Law 2007, Allendorf et al. 2008, Hutchings \& Fraser 2008), studies in freshwater systems are just beginning, and this is particularly true for whitefish fisheries. The first evidence for an evolutionary response to the highly selective harvest of large, fast-growing whitefish was presented by Handford et al. (1977) for Coregonus clupeaformis in Lesser Slave Lake, Canada. For Lake Constance whitefish, Hartmann (1992) plotted time series of condition factor, length-at-age etc., and assumed that decreases in some of these variables over time were evidence of genetic selection caused by intensive gill netting. Through a multivariate regression analysis of back-calculated lengths for Lake Constance whitefish, Thomas \& Eckmann (2007) demonstrated that in addition to standing stock biomass and lake productivity (measured as phosphorus content), calendar year had a highly significant negative impact on fish growth. Over more than four decades from 1955 to 1997 , growth during the second year of life declined by almost $0.6 \mathrm{~cm}$ per decade, which was considered as evidence for an evolutionary response to size-selective harvesting. A very similar conclusion was reached in the analysis of a 25 year survey of Coregonus palaea Cuvier in Lake Joux, Switzerland by Nusslé et al. (2009). The relative change in logarithmic growth per generation was $-4.37 \%$, and the selection differential for logarithmic growth was -4.93 . Assuming a heritability of growth of 0.3 , fishery-induced selection would contribute about $34 \%$ to the observed reduction in growth. The same analyses on two sympatric species in Lake Brienz (Coregonus albellus Fatio and Coregonus fatioi Kottelat) yielded a similar result (Nusslé et al. 2011), and showed furthermore that the selection differentials on juvenile and adult growth, as well as the reduction in growth over the last 25 years, differed between the species. This implies that the link between selection differentials and phenotypic changes is influenced by speciesspecific factors. Unfortunately, the relevance of fishery-induced evolution for the future of whitefish fisheries in European alpine lakes has not yet been fully recognized by fishery managers.

The accelerating spread of non-native aquatic species is generally considered as a potential threat to native biocoenoses. Yet, the arrival of some alien species may bring an advantage for certain natives by improving their food base. The mysid Limnomysis benedeni Czerniavsky is an example of an alien species that might enhance the growth of coregonids. L. benedeni was found in Lake Constance in 2006 and soon established a large population (Hanselmann et al. 2011). Feeding experiments with early juvenile whitefish demonstrated that growth was slightly enhanced in fish fed ad libitum with L. benedeni, compared with conspecifics fed ad libitum with lake zooplankton (Roch 2010). However the future development of the $L$. benedeni population and its possible effect on whitefish growth in the lake cannot yet be predicted, and demands further study.

Naturally, the strongest effects on individual biomass occur during the growth phase, whereas effects on year-class strength seem to be weak during this stage. In recent decades, almost all factors influencing coregonids during their growth phase have tended to depress growth rate, e.g., lake re-oligotrophication, metalimnetic cyanobacteria blooms, increased intraspecific competition for food due to slower growth and hence larger standing stock biomass, and fisheries-induced evolution towards slower growth. There seems to be some potential for improving growth by regulation of standing stock biomass, but the growth rates observed during the peak of anthropogenic eutrophication are unrecoverable. 


\section{The reproductive phase}

Previous analyses of the stock-recruitment relationships of coregonid populations in European alpine lakes have yielded inconsistent results. In the case of Lake Geneva whitefish for example, a dome-shaped Shepherd stock-recruitment model accounted for $41 \%$ of the $1961-$ 1992 recruitment index (Caranhac \& Gerdeaux 1998). For the years 1992-2005, however, the stock-recruitment relationship was no longer dome-shaped, but the recruitment index increased with spawning stock abundance to a previously unknown high (Anneville et al. 2009). In the first period, the depression of cohort size at high stock densities was mainly attributed to cannibalism, but this kind of intraspecific population regulation could not be discerned in more recent years. This fundamental change in the stock-recruitment relationship was attributed to a regime shift in the Lake Geneva ecosystem from a cold, high eutrophic regime to a warm, low eutrophic regime. During the latter regime, egg survival may have improved as a result of declining phosphorus levels. Furthermore, whitefish larvae probably grew faster in recent years due to climate-mediated changes in water temperature and food availability, mitigating the cannibalistic control of cohort size (Anneville et al. 2009).

For Lake Constance whitefish, a stock-recruitment relationship has not been reported so far. Instead, the available analyses suggest cannibalistic control of cohort size, which was found to be inversely related to the density of older conspecifics (Eckmann et al. 1988, Straile et al. 2007). However, an underlying stock-recruitment relationship might have been blurred in this lake due to stocking with delayed hatchery-bred larvae, the density of which increased steadily up to almost 1 larva $\mathrm{m}^{-2}$ during recent decades (Eckmann 2012).

Below some level of spawning stock density, recruitment in any lake will surely be constrained by the number of eggs produced. But the risk of recruitment overfishing similar to that in Lake Constance in the early 1960s (Nümann 1972), is probably insignificant today in most European alpine lakes. Due to re-oligotrophication, whitefish now grow more slowly and are caught at greater age, by which time they have already reproduced at least once. Still, it is worthwhile to consider factors that might influence the reproductive output of a whitefish population, because most populations face changing conditions due to planned or unplanned human impacts on their abiotic and biotic environment.

The fecundity of bony fish is related to body length by a power function in most species (Wootton 1998). This implies that the egg production of a population will decrease disproportionately with a reduction in fish growth due to oligotrophication, even when average cohort size remains unchanged. Furthermore, in Lake Constance whitefish, fecundity decreased in parallel with the decline in phosphorus levels (Thomas et al. 2009). A consequence of this is that the hatcheries of Upper Lake Constance have not been used to capacity during recent years. While the fishery during spawning time yields roughly the same number of spawning fish as before, fewer eggs can be stripped from these fish (Rösch 2011).

On the other hand, slower growth of whitefish may be beneficial in terms of reproductive output. It is a widely accepted notion that first-time spawners produce eggs of lower quality than repeat spawners (Kamler et al. 1982). When age-at-harvest increases due to slower growth, the fraction of repeat spawners in the population will be higher than in a population of fast-growing fish that are harvested at a younger age. This being the case, the quality of the eggs produced by whitefish populations in oligotrophic lakes ought to be better. The egg weight of Lake Constance whitefish does indeed increase with fish size (Rösch 1987) and 
age (Thomas et al. 2009). On average a population that is older will produce heavier eggs, and these eggs will give rise to larger larvae with better survival chances. Thus far however, it has not been demonstrated unequivocally that the age structure of the spawning stock has any measurable effect on cohort size, and documenting such an effect will surely be a challenge for future field studies.

In addition to the phenotypic response of lower egg production due to smaller size, sizeselective harvesting may evoke evolutionary responses in reproductive traits. An intensive, size-selective fishery will harvest predominantly those females that allocate energy to reproduction late in life, favouring those that mature younger and smaller. The second possible effect of intensive size-selective harvesting is an increase in fecundity, because females that allocate a greater fraction of available energy into reproduction early in life produce more eggs overall and enhance their reproductive success. And finally, when hatchery-bred larvae form a significant portion of the adult stock, the size-selective harvest of spawning stock will favour females with high fecundity (probably, but not necessarily, in combination with larger egg size), because these females have a larger body girth and are more likely to be caught in the spawning fishery (Thomas et al. 2009).

The reproduction of whitefish may also be severely compromised by pathological changes to reproductive organs or to general reproductive physiology. A spectacular case was reported from Lake Thun, Switzerland, where various types of gonad deformation among four whitefish forms were detected by fishers in 2000 (Bernet et al. 2004, Bittner et al. 2009). A comprehensive research project ruled out a series of candidate agents (Bernet et al. 2008) and finally concluded that disregulation of the immune system leading to chronic autoimmune disease was the most likely cause of the pathological symptoms. The reproduction of the fish, however, seems not to have been constrained by the gonad deformations, even though the symptoms look rather alarming.

In summary, the factors influencing coregonids during their reproductive phase seem to have a moderate effect on year-class strength. Climate-mediated changes in the stockrecruitment relationship may increase year-class strength, while lower lake productivity will decrease a population's reproductive output in quantitative and perhaps also in qualitative terms. The effects of intensive size-selective fishery are not yet fully understood, and seem to be ambiguous. As there is a trade-off between energy allocated to reproduction and to growth, changes in reproductive output may influence the growth potential of offspring to the extent that the pattern of energy allocation has a hereditary component.

\section{Future challenges}

New forms of anthropogenic impact on coregonid populations will continue to challenge researchers in European alpine lakes in the near future, and they will require the development of new, unconventional strategies for the management of coregonid stocks. The abatement of anthropogenic eutrophication has been the central target in the management of European alpine lakes during the past decades. The return of many of these lakes to near-pristine oligotrophic conditions is an outstanding success of the environmental protection measures that have been taken in the past. Under ultra-oligotrophic conditions, however, fishery yields decline to levels that hardly allow for a profitable commercial fishery, and in parallel to the 
gradual dwindling of a traditional profession, European alpine lakes may lose part of their touristic attractiveness. Setting a minimum for phosphorus concentration (e.g. $10 \mu \mathrm{g} \mathrm{PO}_{4}-\mathrm{P}$ $\mathrm{L}^{-1}$ during holomixis), a measure that is currently impossible in most countries due to environmental protection legislation, might avoid the depression of YCS (Rellstab et al. 2004), and may enhance individual biomass of whitefish by boosting secondary production. Neither touristic activities nor the supply of drinking water would be impaired, as amply demonstrated by comparably high phosphorus concentrations in these lakes in the past.

The effects of climate change on the embryonic and larval phases of coregonids are already the focus of research institutes, while problems arising from the appearance of cyanobacterial blooms are also receiving increased attention. Non-native aquatic species do not pose a threat to European alpine coregonid stocks at the moment, but more species will surely colonise these lakes in the near future, and the effects on coregonid stocks need to be monitored. While the profitability of the professional fishery is declining, the share in total harvests taken by anglers is increasing. The implications of these changes in the harvest regime need to be thoroughly considered, as for example in Lake Annecy (Wojtenka et al. 1988).

Fishery-induced evolution is a topic of prime concern in the marine fisheries. Among freshwater fishery managers, at European alpine lakes in particular, this problem has been largely neglected thus far. This may be because the effects of fishery-induced evolution on coregonid stocks are not apparent at first sight, and their impact on harvests may be perceived as weak. Yet, the precautionary principle in natural resource management requires that possible effects of fishery-induced evolution on coregonid stocks be taken into account and that attempts be made in cooperation with biologists and fishermen to develop possible countermeasures.

Supportive stocking with hatchery-bred larvae, pre-fed larvae and juveniles is widely practiced in many European alpine lakes. The effectiveness and usefulness of this practice, however, have hardly ever been seriously evaluated (Eckmann 2012). Thanks to successful re-oligotrophication, spawning ground quality has improved in many lakes to such an extent that natural reproduction is fully functional, and supportive stocking is probably no longer required. In the interests of nature conservation and economic considerations it may soon be necessary to decide on a case-by-case basis whether stocking is to be continued as before, in a modified form, or completely abolished.

In summary, it appears that in a rapidly changing, globalized world, maintaining coregonid stocks in European alpine lakes is a challenge that will continue to require at least as much research as during past decades.

\section{Acknowledgements}

I am grateful to Josef Wanzenböck who suggested to review the population dynamics of whitefish, focussing particularly on studies done in European alpine lakes, and who gave me the opportunity to present this review as a keynote lecture during the 2011 symposium in Mondsee. Amy Jane Beer corrected the English and streamlined the text. 


\section{References}

Allendorf, F. W., England, P. R., Luikart, G., Ritchie, P. A. \& Ryman, N., 2008: Genetic effects of harvest on wild animal populations. Trends Ecol. Evol. 23: 327-337.

Anneville, O., Souissi, S., Molinero, J. C. \& Gerdeaux, D., 2009: Influences of human activity and climate on the stock-recruitment dynamics of whitefish, Coregonus lavaretus. Lake Geneva. Fisheries Manag. Ecol. 16: 492-500.

Bailey, K. M. \& Houde, E. D., 1989: Predation on eggs and larvae of marine fishes and the recruitment problem. Adv. Mar. Biol. 25: 1-83.

Becker, M. \& Eckmann, R., 1992: Plankton selection by pelagic European whitefish in Lake Constance: Dependency on season and time of day. Pol. Arch. Hydrobiol. 39: 393-402.

Bernet, D., Wahli, T., Kueng, C. \& Segner, H., 2004: Frequent and unexplained gonadal abnormalities in whitefish (central alpine Coregonus sp.) from an alpine oligotrophic lake in Switzerland. Dis. Aquat. Organ. 61: 137-148.

Bernet, D., Liedtke, A., Bittner, D., Eggen, R. I. L., Kipfer, S., Kueng, C., Largiader, C. R., Suter, M. J. F., Wahli, T. \& Segner, H., 2008: Gonadal malformations in whitefish from Lake Thun: Defining the case and evaluating the role of EDCs. Chimia. 62: 383-388.

Bittner, D., Bernet, D., Wahli, T., Segner, H., Kueng, C. \& Largiader, C. R., 2009: How normal is abnormal? Discrimination between deformations and natural variation in gonad morphology of European whitefish Coregonus lavaretus. J. Fish Biol. 74: 1594-1614.

Braum, E., 1964: Experimentelle Untersuchungen zur ersten Nahrungsaufnahme und Biologie an Jungfischen von Blaufelchen (Coregonus wartmanni Bloch), Weißfelchen (Coregonus fera Jurine) und Hechten (Esox lucius L.). Arch. Hydrobiol. Suppl. Falkau-Arbeiten 28: 183-244.

Braum, E., 1967: The survival of fish larvae with reference to their feeding behaviour and the food supply. - In: Gerking, S.D. (ed.): The Biological Basis of Freshwater Fish Production. Blackwell Scientific Publications, Oxford and Edinburgh: pp. 113-131.

Braum, E. \& Quos, H., 1981: Beobachtungen über die Eientwicklung des Blaufelchens (Coregonus lavaretus wartmanni) im Bodensee-Obersee. Schweiz. Z. Hydrol. 43: 114-125.

Brooke, L. T. \& Colby, P. J., 1980: Development and survival of embryos of lake herring at different constant oxygen concentrations and temperatures. Prog. Fish. Cult. 42: 3-9.

Busch, S., Johnson, B. M., Mehner, T. \& Post, J. R., 2011: Energetic costs and benefits of cyclic habitat switching: a bioenergetics model analysis of diel vertical migration in coregonids. Can. J. Fish. Aquat. Sci. 68: 706-717.

Büttiker, B., 1986: In-situ observations on coregonid eggs survival in Lake Joux, Switzerland. Arch. Hydrobiol. Beih. Ergebn. Limnol. 22: 353-362.

Caranhac, F. \& Gerdeaux, D., 1998: Analysis of the fluctuations in whitefish (Coregonus lavaretus) abundance in Lake Geneva. Arch. Hydrobiol. Spec. Issues Advanc. Limnol. 50: 197-206.

Cushing, D. H., 1990: Plankton production and year-class strength in fish populations - an update of the match mismatch hypothesis. Adv. Mar. Biol, 26: 249-293.

Czerkies, P., Brzuzan, P., Kordalski, K. \& Luczynski, M., 2001: Critical partial pressures of oxygen causing precocious hatching in Coregonus lavaretus and C. albula embryos. Aquaculture. 196: 151158.

Eckmann, R., 1985: Histopathological alterations in the intestine of whitefish (Coregonus sp.) larvae reared on zooplankton from Lake Constance. Dis. Aquat. Organ. 1: 11-17.

Eckmann, R., 1989: The distribution of coregonid larvae Coregonus lavaretus and Coregonus fera from Lake Constance in a vertical temperature gradient. Pol. Arch. Hydrobiol. 36: 485-494.

Eckmann, R., 2012: Massive stocking with hatchery larvae may constrain natural recruitment of whitefish stocks and induce unwanted evolutionary changes. Arch. Hydrobiol. Spec. Issues Advanc. Limnol. 63: 325-336.

Eckmann, R., Gaedke, U. \& Wetzlar, H. J., 1988: Effects of climatic and density-dependent factors on year-class strength of Coregonus lavaretus in Lake Constance. Can. J. Fish. Aquat. Sci. 45: 10881093. 
Eckmann, R., Gerdeaux, D., Müller, R. \& Rösch, R., 2007: Re-oligotrophication and whitefish fisheries management - a workshop summary. Arch. Hydrobiol. Spec. Issues Advanc. Limnol. 60: 353-360.

Eckmann, R. \& Pusch, M., 1989: The influence of temperature on growth of young coregonids (Coregonus lavaretus L.) in a large prealpine lake. Rapp. P.-v. Réun. Cons. int. Explor. 191: 201-208.

Eckmann, R. \& Pusch, M., 1991: At what life stage is year-class strength of coregonids (Coregonus lavaretus L.) in Lake Constance determined? Verh. Internat. Verein. Limnol. 24: 2465-2469.

Eckmann, R. \& Rösch, R., 1998: Lake Constance fisheries and fish ecology. Arch. Hydrobiol. Spec. Issues Advanc. Limnol. 53: 285-301.

Eckmann, R., Rösch, R., Ortlepp, J. \& Kleifeld, G., 1986: Survival and growth of coregonid larvae from Lake Constance central Europe fed on zooplankton of different origin. Arch. Hydrobiol. Beih. Ergebn. Limnol. 22: 203-214.

Einsele, W., 1941: Fischereiwissenschaftliche Probleme in deutschen Alpenseen. Fischerei-Ztg., 1-16.

Elster, H.-J., 1944: Über das Verhältnis von Produktion, Bestand, Befischung und Ertrag sowie über die Möglichkeiten einer Steigerung der Erträge, untersucht am Beispiel der Blaufelchenfischerei des Bodensees. Zeitschr. f. Fischerei u. d. Hilfswiss. 42: 170-357.

Enz, C. A., Burgi, H. R., Stossel, F. \& Müller, R., 2001: Food preference of adult whitefish in eutrophic Lake Hallwil (Switzerland), and the question of cannibalism. Arch. Hydrobiol. 152: 81-98.

Ernst, B., Hitzfeld, B. \& Dietrich, D., 2001: Presence of Planktothrix sp and cyanobacterial toxins in Lake Ammersee, Germany and their impact on whitefish (Coregonus lavaretus L.). Environ. Toxicol. 16: $483-488$.

Ernst, B., Hoeger, S. J., O'Brien, E. \& Dietrich, D., 2006: Oral toxicity of the microcystin-containing cyanobacterium Planktothrix rubescens in European whitefish (Coregonus lavaretus). Aquat. Toxicol. 79: 31-40.

Folkvord, A., 1993: Prey recognition in stomachs of cannibalistic juvenile cod (Gadus morhua L.). Sarsia. 78: 97-100.

Fudge, R. J. P. \& Bodaly, R. A., 1984: Postimpoundment winter sedimentation and survival of lake whitefish (Coregonus clupeaformis) eggs in Southern Indian Lake, Manitoba. Can. J. Fish. Aquat. Sci. 41: 701-705.

Gerdeaux, D., 2004: The recent restoration of the whitefish fisheries in Lake Geneva: the roles of stocking, reoligotrophication, and climate change. Ann. Zool. Fenn. 41: 181-189.

Gerdeaux, D. \& Dewaele, P., 1986: Effects of the weather and of artificial propagation on coregonid catches in Lake Geneva, Switzerland, France. Arch. Hydrobiol. Beih. Ergebn. Limnol. 22: 343-352.

Gerdeaux, D., Bergeret, S., Fortin, J. \& Baronnet, T., 2002: Diet and seasonal patterns of food composition of Coregonus lavaretus in Lake Annecy: Comparison with the diet of the other species of the fish community. Arch. Hydrobiol. Spec. Issues Advanc. Limnol. 57: 199-207.

Haakana, H. \& Huuskonen, H., 2009: Predation of smelt on vendace larvae: experimental and field studies. Ecol. Freshw. Fish 18: 226-233.

Häkkinen, J., Vehniäinen, E., Ylönen, O., Heikkilä, J., Soimasuo, M., Kaurola, J., Oikari, A. \& Karjalainen, J., 2002: The effects of increasing UV-B radiation on pigmentation, growth and survival of coregonid embryos and larvae. Environ. Biol. Fish. 64: 451-459.

Hamrin, S. F. \& Persson, L., 1986: Asymmetrical competition between age classes as a factor causing population oscillations in an obligate planktivorous fish species. Oikos 47: 223-232.

Handford, P., Bell, G. \& Reimchen, T., 1977: Gillnet fishery considered as an experiment in artificial selection. J. Fish. Res. Board. Can. 34: 954-961.

Hanselmann, A. J., Gergs, R. \& Rothhaupt, K.-O., 2011: Seasonal shifts in the life cycle of the ponto-caspian invader Limnomysis benedeni (Crustacea: Mysida): a physiological adaptation? Hydrobiologia 673: 193-204.

Hanzelova, V., Scholz, T., Gerdeaux, D. \& de Chambrier, A., 1999: Endoparasitic helminths of fishes in three alpine lakes in France and Switzerland. Rev. Suisse Zool. 106: 581-590.

Hartmann, J., 1983a: Fangaussichten bei Felchen (Jahrgänge 1981-83) und Barsch (Jgg. 1980-82) des Bodensees. Der Fischwirt. 10: 69-70.

Hartmann, J., 1983b: Two feeding strategies of young fishes. Arch. Hydrobiol. 96: 496-509.

Hartmann, J., 1986: Interspecific predictors of selected prey of young fishes. - Arch. Hydrobiol. Beih. Ergebn. Limnol. 22: 373-386. 
Hartmann, J., 1987: Whitefish as indicators of cultural eutrophication. Schweiz. Z. Hydrol. 49: 343352.

Hartmann, J., 1988: Ist die Rekrutierung (Jahrgangsstärke) beim Bodenseefelchen (Coregonus lavaretus) schon verstanden? Österr. Fisch. 41: 135-142.

Hartmann, J., 1992: Rückgang von Kondition und Wachstum bei Felchen (Coregonus lavaretus) durch selektive Kiemennetzbefischung. Fischökologie 6: 21-30.

Heege, T. \& Appenzeller, A. R., 1998: Correlations of large-scale patterns of turbidity and pelagic fish biomass using satellite and acoustic methods. Arch. Hydrobiol. Spec. Issues Advanc. Limnol. 53: 489-503.

Hutchings, J. A. \& Fraser, D. J., 2008: The nature of fisheries- and farming-induced evolution. Mol. Ecol. 17: 294-313.

Kahilainen, K. K., Malinen, T. \& Lehtonen, H., 2009: Polar light regime and piscivory govern diel vertical migrations of planktivorous fish and zooplankton in a subarctic lake. Ecol. Freshw. Fish 18: $481-490$.

Kamler, E., Zuromska, H. \& Nissinen, T., 1982: Bioenergetic evaluation of environmental and physiological factors determining egg quality and growth in Coregonus albula. Pol. Arch. Hydrobiol. 29: 71-122.

Kirchhofer, A., 1995: Growth characteristics of coregonid populations in three lakes with different trophic states and decreasing nutrient concentrations. Arch. Hydrobiol. Spec. Issues Advanc. Limnol. 46: $61-70$.

Kirchhofer, A. \& Tschumi, P. A., 1986: Age structure and growth of coregonid fish populations in Lake Thun, Switzerland. Arch. Hydrobiol. Beih. Ergebn. Limnol. 22: 303-318.

Kopfmüller, A. \& Scheffelt, E., 1924: Blaufelchenlaich und klimatische Faktoren. Schr. Ver. Gesch. Bodensee 53: 35-56.

Kottelat, M. \& Freyhof, J., 2007: Handbook of European Freshwater Fishes. Publications Kottelat, Cornol, $646 \mathrm{pp}$.

Law, R., 2007: Fisheries-induced evolution: present status and future directions. Mar. Ecol. Prog. Ser. 335: $271-277$.

Lechler, H., 1929: Untersuchungen über die Reinanke des Mondsees. Ztschr. Fischerei 27: 547-560.

Loftus, D. H. \& Hulsman, P. F., 1986: Predation on larval lake whitefish (Coregonus clupeaformis) and lake herring (Coregonus artedii) by adult rainbow smelt (Osmerus mordax). Can. J. Fish. Aquat. Sci. 43: $812-818$.

Marjomäki, T. J. \& Kirjasniemi, J., 1995: Density dependent growth of vendace (Coregonus albula (L.)) in Lake Puulavesi: A modelling analysis. Arch. Hydrobiol. Spec. Issues Advanc. Limnol. 46: 89-96.

Mayr, C., 2001: The influence of population density on growth of whitefish (Coregonus lavaretus L.) in four prealpine lakes. Limnologica 31: 53-60.

Mayr, C., 2002: The effect of water turbidity on distribution and feeding success of European whitefish (Coregonus lavaretus L.). Arch. Hydrobiol. Spec. Issues Advanc. Limnol. 57: 265-275.

Mehner, T., Kasprzak, P. \& Hölker, F., 2007: Exploring ultimate hypotheses to predict diel vertical migrations in coregonid fish. Can. J. Fish. Aquat. Sci. 64: 874-886.

Miller, T. J., Crowder, L. B., Rice, J. A. \& Marschall, E. A., 1988: Larval size and recruitment mechanisms in fishes: toward a conceptual framework. Can. J. Fish. Aquat. Sci. 45: 1657-1670.

Mills, K. H., Chalanchuk, S. M., Allan, D. J. \& Mohr, L. C., 1995: Responses of lake whitefish (Coregonus clupeaformis) to exploitation at the experimental lakes area, northwestern Ontario. Arch. Hydrobiol. Spec. Issues Advanc. Limnol. 46: 361-368.

Mookerji, N., Heller, C., Meng, H. J., Burgi, H. R. \& Müller, R., 1998: Diel and seasonal patterns of food intake and prey selection by Coregonus sp. in re-oligotrophicated Lake Lucerne, Switzerland. J. Fish Biol. 52: 443-457.

Morscheid, H. \& Mayr, C., 2002: Supply and demand: The interplay of vertical distribution of European whitefish (Coregonus lavaretus L.) and zooplankton in Lake Ammersee. Arch. Hydrobiol. Spec. Issues Advanc. Limnol. 57: 411-421.

Müller, R., 1992: Trophic state and its implications for natural reproduction of salmonid fish. Hydrobiologia 243: 261-268. 
Müller, R., 1993: Einige fischereibiologische Aspekte von Seesanierungen. Fortschr. Fisch.wiss. 11: 43-56.

Müller, R. \& Bia, M. M., 1998: Adaptive management of whitefish stocks in lakes undergoing reoligotrophication: The Lake Lucerne example. Arch. Hydrobiol. Spec. Issues Advanc. Limnol. 50: 391-399.

Müller, R. \& Stadelmann, P., 2004: Fish habitat requirements as the basis for rehabilitation of eutrophic lakes by oxygenation. Fisheries Manag. Ecol. 11: 251-260.

Niesslbeck, P. \& Klein, M., 1988: Growth conditions of naturally hatched and artificially bred larvae of Coregonus lavaretus L. sensu lato in Lake Starnberg, Bavaria, West Germany. Finnish Fish. Res. 9: $361-372$.

Nümann, W., 1972: The Bodensee: effects of exploitation and eutrophication on the salmonid community. J. Fish. Res. Board. Can. 29: 833-847.

Nümann, W., 1973: Versuch einer Begründung für den Wandel in der qualitativen und quantitativen Zusammensetzung des Fischbestandes im Bodensee während der letzten 60 Jahre und eine Bewertung der Besatzmassnahmen. Schweiz. Z. Hydrol. 35: 206-238.

Nümann, W. \& Quoß, H., 1972: Strudelwürmer dezimieren den Felchenlaich - Ursachen für die unterschiedlichen Fangerträge in der Blaufelchen-Fischerei des Bodensees. Der Fischwirt 4: 25-27.

Nusslé, S., Bornand, C. N. \& Wedekind, C., 2009: Fishery-induced selection on an Alpine whitefish: quantifying genetic and environmental effects on individual growth rate. Evol. Appl. 2: 200-208.

Nusslé, S., Brechon, A. \& Wedekind, C., 2011: Change in individual growth rate and its link to gill-net fishing in two sympatric whitefish species. Evol. Ecol. 25: 681-693.

Pedroli, P. J.-C., 1983: Les corégones du lac de Neuchâtel: rendement de la pêche; âge et croissance des individus capturés par les pêcheurs professionnels. Schweiz. Z. Hydrol. 45: 345-358/360.

Ponton, D. \& Müller, R., 1988: Distribution and food of larval and juvenile Coregonus sp in Lake Sarnen, Switzerland. Finnish Fish. Res. 9: 117-126.

Rellstab, C., Burgi, H. R. \& Müller, R., 2004: Population regulation in coregonids: the significance of zooplankton concentration for larval mortality. Ann. Zool. Fenn. 41: 281-290.

Rey, P. \& Eckmann, R., 1989: The influence of lake temperature on growth on Coregonus lavaretus L larvae. Arch. Hydrobiol. 116: 181-190.

Roch, S., 2010: Die Qualität von Limnomysis benedeni als Futter für junge Felchen im Bodensee. BScthesis, University of Konstanz, 35+4 pp.

Rösch, R., 1987: Egg-size of pelagic and nearshore spawning coregonids (Coregonus lavaretus L.) from Lake Constance correlated with the fish weight. Arch. Hydrobiol. 109: 519-523.

Rösch, R., 2011: Felchen-Laichfischerei 2010 im Bodensee-Obersee. Fischereiinformationen aus Baden-Württemberg. 1: 8-11.

Rösch, R. \& Schmid, W., 1996: Ruffe (Gymnocephalus cernuus L.), newly introduced into Lake Constance: Preliminary data on population biology and possible effects on whitefish (Coregonus lavaretus L.). Ann. Zool. Fenn. 33: 467-471.

Rufi, H., 1979: Ernährung und Wachstum der Felchenpopulationen (Coregonus spp.) des Thuner- und Bielersees. Schweiz. Z. Hydrol. 41: 64-93.

Ruhle, C., 1988: Preliminary results of investigations on the biology of slow-growing whitefish Coregonus lavaretus L. in Lake Walenstadt, Switzerland. Finnish Fish. Res. 9: 175-182.

Ruhle, C. \& Gammeter, S., 1998: Alterations in the trophic status of Lake Walenstadt (Switzerland) and in the growth of its slow-growing whitefish (Coregonus lavaretus L.). Arch. Hydrobiol. Spec. Issues Advanc. Limnol. 50: 109-120.

Scheffelt, E. \& Schweizer, W., 1926: Fische und Fischerei im Bodensee. Enke, Stuttgart.

Schmid, W., 1998: Coregonus lavaretus ova predation by newly introduced ruffe (Gymnocephalus cernuus L.) in Lake Constance, Germany. Arch. Hydrobiol. Spec. Issues Advanc. Limnol. 50: 179_ 183.

Schooley, J. D., Karam, A. P., Kesner, B. R., Marsh, P.C., Pacey, C. A. \& Thornbrugh, D. J., 2008: Detection of larval remains after consumption by fishes. Trans. Am. Fish. Soc. 137: 1044-1049.

Seebens, H., Straile, D., Hoegg, R., Stich, H. B. \& Einsle, U., 2007: Population dynamics of a freshwater calanoid copepod: Complex responses to changes in trophic status and climate variability. Limnol. Oceanogr. 52: 2364-2372. 
Skurdal, J., Bleken, E. \& Stenseth, N. C., 1985: Cannibalism in whitefish (Coregonus lavaretus). Oecologia 67: 566-571.

Steinhart, M. \& Eckmann, R., 1992: Evaluating the nutritional condition of individual whitefish Coregonus spp larvae by the RNA-DNA ratio. J. Fish Biol. 40: 791-799.

Straile, D., Eckmann, R., Jüngling, T., Thomas, G. \& Löffler, H., 2007: Influence of climate variability on whitefish (Coregonus lavaretus) year-class strength in a deep, warm monomictic lake. Oecologia 151: 521-529.

Straile, D., Kerimoglu, O., Peeters, F., Jochimsen, M. C., Kümmerlin, R., Rinke, K. \& Rothhaupt, K.O., 2010: Effects of a half a millennium winter on a deep lake - a shape of things to come? Global Change Biol. 16: 2844-2856.

Thomas, G. \& Eckmann, R., 2007: The influence of eutrophication and population biomass on common whitefish (Coregonus lava retus) growth - the Lake Constance example revisited. Can. J. Fish Aquat. Sci. 64: 402-410.

Thomas, G., Quoss, H., Hartmann, J. \& Eckmann, R., 2009: Human-induced changes in the reproductive traits of Lake Constance common whitefish (Coregonus lavaretus). J. Evolution. Biol. 22: 88-96.

Todd, T. N. \& Davis, B. M., 1995: Effects of fish density and relative abundance on competition between larval lake herring and lake whitefish for zooplankton. Arch. Hydrobiol. Spec. Issues Advanc. Limnol. 46: 163-171.

Ventling-Schwank, A. R. \& Livingstone, D. M., 1994: Transport and burial as a cause of whitefish (Coregonus sp) egg mortality in a eutrophic lake. Can. J. Fish. Aquat. Sci. 51: 1908-1919.

Wagler, E., 1941: Handbuch der Binnenfischerei Mitteleuropas. In: Demoll, R. \& Maier, H. (Eds.), Die Lachsartigen (Salmonidae), II. Teil, Coregonen. E. Schweizerbart'sche Verlagsbuchhandlung, Stuttgart, pp. 371-501.

Wahl, B. \& Löffler, H., 2009: Influences on the natural reproduction of whitefish (Coregonus lavaretus) in Lake Constance. Can. J. Fish. Aquat. Sci, 66: 547-556.

Wanzenböck, J., Gassner, H., Lahnsteiner, B., Hassan, Y., Hauseder, G., Christine, D. \& Köck, G., 2002: Ecological integrity assessment of lakes using fish communities: An example from Traunsee exposed to intensive fishing and to effluents from the soda industry. Water, Air and Soil Pollution: Focus. 2: 227-248.

Wetzlar, H. J., 1983: Zur Interpretation der Coregonenerträge im Bodensee. Der Fischwirt 33: 74.

Winfield, I. J., Fletcher, J. M. \& Cubby, P. R., 1998a: The threat to vendace (Coregonus albula) eggs from introduced ruffe (Gymnocephalus cernuus) in Bassenthwaite Lake, U. K. Arch. Hydrobiol. Spec. Issues Advanc. Limnol. 50: 171-177.

Winfield, I. J., Rösch, R., Appelberg, M., Kinnerback, A. \& Rask, M., 1998b: Recent introductions of the ruffe (Gymnocephalus cernulus) to Coregonus and Perca lakes in Europe and an analysis of their natural distributions in Sweden and Finland. J. Great Lakes Res. 24: 235-248.

Wojtenka, J., Gerdeaux, D. \& Allardi, J., 1988: Coregonid fishery in Lake Annecy-an example of dual exploitation. Finnish Fish. Res. 9: 389-396.

Wootton, R. J., 1998: Ecology of Teleost Fishes. Kluwer Academic Publishers, Dordrecht / Boston / London, $386 \mathrm{pp}$.

Ylönen, O. \& Karjalainen, J, 2004: Growth and survival of European whitefish larvae under enhanced UV-B irradiance. J. Fish Biol. 65: 869-875. 